\title{
Awareness of analgesics complications in Saudi Arabia: a cross-sectional study
}

\author{
Amal I. Siddig ${ }^{1}$, Abdulhadi M. Alqahtani ${ }^{2^{*}}$ (D), Alia AlShalawi ${ }^{3}$, Marwah Turkistani ${ }^{3}$, Sarah Binbaz ${ }^{3}$ and \\ Amal Altowairqi ${ }^{3}$
}

\begin{abstract}
Background: All over the world, analgesics are considered one of the most widely used and abused medications. Painkillers such as paracetamol (acetaminophen), non-steroidal anti-inflammatory drugs (NSAIDs), and aspirin currently represent the principal means of pain management. Unfortunately, paracetamol and NSAIDs have dangerous side effects primarily when they are used improperly and without respect to safety rules. This study aims to assess the awareness of the indications, complications, and contraindications of commonly used analgesics.

Results: A total of 1554 participants responded to the survey, and the findings indicated that the main analgesic used is paracetamol. A proportion of $68.1 \%$ of the total number of respondents received their information about analgesic medications from a physician or pharmacist; $95.7 \%$ used analgesics when needed, and $70.9 \%$ mentioned that they would consult a physician or pharmacist if the pain was not relieved after the use of over-the-counter medications. Nearly $29 \%$ were not aware of the possibility of adverse effects of analgesic use.

Conclusion: The most commonly used analgesic is paracetamol, and most of the participants had a poor level of awareness regarding the complications and side effects of analgesics in general. Our recommendation is to conduct a continuous health education campaign about the use of analgesics.
\end{abstract}

Keywords: Awareness, Analgesic complications, Paracetamol

\section{Background}

Painkillers are considered globally as one of the most abused medications. Pain is defined as an actual or potential tissue damage associated with an unpleasant emotional and sensory experience. Analgesics such as acetaminophen, non-steroidal anti-inflammatory drugs (NSAIDs), and aspirin currently represent the principal means of pain management [1].

NSAIDs are medications with anti-inflammatory, analgesic, and antipyretic actions, and some inhibit the platelet aggregation $[2,3]$, while paracetamol has antipyretic and analgesic effects [4]. Inflammatory conditions comprise the most prevalent indications for NSAID use. However, for fever and pain disorders, paracetamol and NSAIDs are considered as the first-line treatment [5].

Unfortunately, paracetamol and NSAIDs have dangerous side effects, especially when they are used with no respect to safety rules and in improper ways, such as

\footnotetext{
* Correspondence: Ph.Abdalhadi@gmail.com

${ }^{2}$ General Department of Research and Studies in Ministry of Health, Riyadh,

Saudi Arabia

Full list of author information is available at the end of the article
}

without consulting a physician or pharmacist or being taken repeatedly without a prescription. They are not only associated with gastrointestinal tract, liver, nervous system, hematological, and kidney complications, but they can have adverse effects on almost every organ [6-9]. A cohort survey analysis conducted among people who are NSAID abusers showed a higher risk of ulcers compared to non-users of NSAIDs. Hence, the increased use of NSAIDs increases the risk of ulcers and, therefore, of bleeding, which can threaten the patient's life [10-13].

NSAIDs are contraindicated in patients who have an allergy to NSAIDs, severe kidney and liver insufficiency, an active peptic ulcer, and hemorrhagic diathesis, as well as those who are pregnant or breastfeeding [14]. Moreover, paracetamol is contraindicated in patients with severe renal or hepatic failure, methemoglobin reductase, or glucose-6phosphate dehydrogenase deficiencies and in patients with allergies to any ingredients of the drug formula [15].

An assessment through a survey study of Taif University students' knowledge, attitudes, and practices regarding medication use is essential for identifying gaps in these 
domains. The gaps can be the starting point of future educational programs to raise public awareness around the identified misconceptions. Therefore, this study was designed to identify the most common analgesics used by Taif University students. It was conducted mainly to assess the knowledge and awareness of Taif University students regarding the indications, complications, and contraindications of the most frequently used analgesics.

\section{Methods}

A cross-sectional study was designed using an electronic questionnaire that was distributed to students at Taif University to assess their knowledge, attitude, and practice regarding analgesic use and their awareness about analgesic complications. The questionnaire was distributed over 6 months starting in January 2018. In this study, we included male and female students from Taif University, regardless of their colleges or departments, as a randomized sample.

\section{Questionnaire design}

We designed the questionnaire based on many previous studies $[16,17]$. We then tested its validation by distributing it to a small sample of the target group to ensure they understood the questionnaire. They understood all the questions, indicating that the questionnaire was clear and understandable. The questionnaire was divided into five sections: (I) the participants' demographic data, which included age, gender, residence, and university level; (II) the participants' knowledge, attitude, and practice regarding analgesics; (III) the participants' knowledge and awareness about paracetamol; (IV) the participants' knowledge and awareness about aspirin; and (V) the participants' knowledge and awareness about ibuprofen.

\section{Statistical analysis}

The data were analyzed using the Statistical Package for the Social Sciences software (SPSS version 25). Descriptive data were presented in frequencies and percentages.

\section{Results}

\section{Demographic characteristics of respondents}

The number of participants in this study was 1554 students from various university faculties. The age of most participants was between 19 and 22 years (53.47\%). The percentage of female participants was $58.9 \%$ while that of male participants was $41.1 \%$. A majority of $91.8 \%$ of the respondents lived in cities, while only $8.17 \%$ lived in villages. Third year university students were the main contributors to this study (20.3\%), whereas only $8.9 \%$ of the participants were postgraduate students (see Table 1).
Table 1 Background characteristic $(n=1554)$

\begin{tabular}{llll}
\hline Variables & & Number & Percent \\
\hline Age groups (years) & Less than 19 & 89 & 5.74 \\
& $19-22$ & 831 & 53.47 \\
& $23-25$ & 502 & 32.3 \\
Gender & More than 25 & 132 & 8.49 \\
\multirow{3}{*}{ Residency } & Female & 915 & 58.9 \\
& Male & 639 & 41.1 \\
Academic year & City & 1427 & 91.8 \\
& Village & 127 & 8.17 \\
& First & 159 & 10.2 \\
& Second & 220 & 14.2 \\
& Third & 315 & 20.3 \\
& Forth & 295 & 19 \\
& Fifth & 241 & 15.5 \\
& Sixth & 186 & 12 \\
& Postgraduate & 138 & 8.9 \\
\hline
\end{tabular}

Participants' knowledge, attitude, and practice regarding analgesics

The most commonly used drug was paracetamol, used by $77.3 \%$ of the study participants. $95.7 \%$ of the participants mentioned that they use it only when necessary, while $4.3 \%$ use it regularly (Fig. 1). $70.9 \%$ of the students said if it did not subside after taking one dose of an analgesic, he will ask a physician or pharmacist, while a few mentioned increasing the dose or using another analgesic if their pain was not relieved $(8.5 \%$ and $20.5 \%$, respectively) (Fig. 2). A small percentage of participants (8.6\%) thought that increasing the dose of the analgesic would have no side effects (Table 2).

In terms of knowledge about the use of paracetamol, a small proportion $(2.3 \%)$ of the students answered that they believed they could use more than eight tablets within $24 \mathrm{~h}$. Seventy-two percent realized that paracetamol could cause liver failure, whereas $28 \%$ did not. A significant proportion of those who participated lacked knowledge about the side effects and contraindications of paracetamol (52.8\% and $34.9 \%$, respectively) (Table 3 ).

Regarding the knowledge about and attitudes towards aspirin, $3.2 \%$ of the participants used more than six tablets of aspirin per day, while a majority of $89.2 \%$ did not use it. There was a significant deficiency in the participants' knowledge about the side effects of aspirin. 56.7\% of the participants did not know the possible side effects of aspirin, and $42.9 \%$ did not know that it can cause bleeding. Also, there was a considerable lack of knowledge about aspirin's contraindications, with $38.8 \%$ of the participants unaware of them (Table 4).

We also noted a lack of awareness about the side effects and complications of ibuprofen, with 58.3\% and 


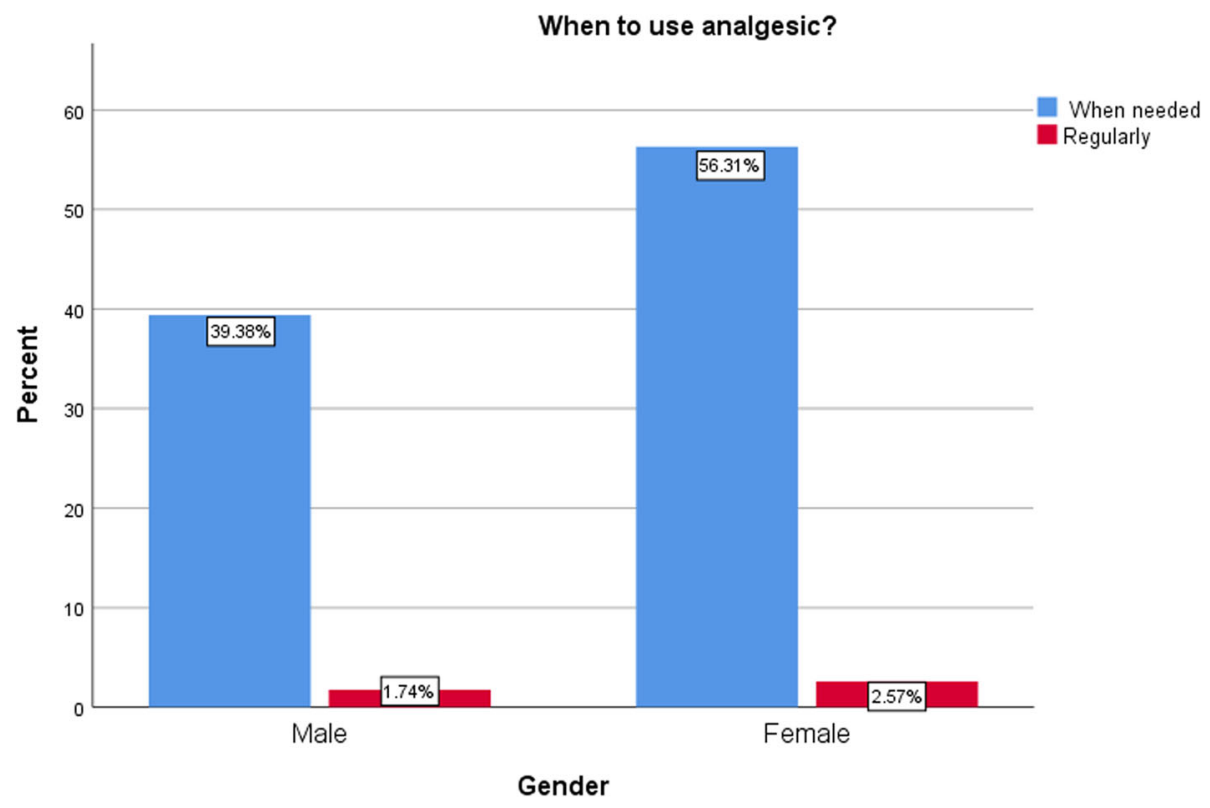

Fig. 1 The percentage of gender by when to use analgesics

$53.9 \%$ of participants unaware of the side effects and contraindications, respectively. A significant percentage of the respondents did not use ibuprofen, but among those who did, $1.3 \%$ used more than four tablets per day. Note that the researchers depended on the National Health Service (NHS) guidelines about safe doses [18] (Table 5).

\section{Discussion}

In this study, we identified paracetamol as the most common analgesic used. Most of the participants in this study were between 19 and 25 years old. It is crucial that this age group has adequate knowledge and awareness about medications because they are the most important link between those under the age of 18 and over 25. According to this ratio, these results are consistent with studies conducted in Saudi Arabia and Norway [16, 19] and are not consistent with others in the USA [20].

The most commonly used type of analgesic in Saudi Arabia is paracetamol, which is consistent with the results of previous studies $[16,19,21]$. There is a

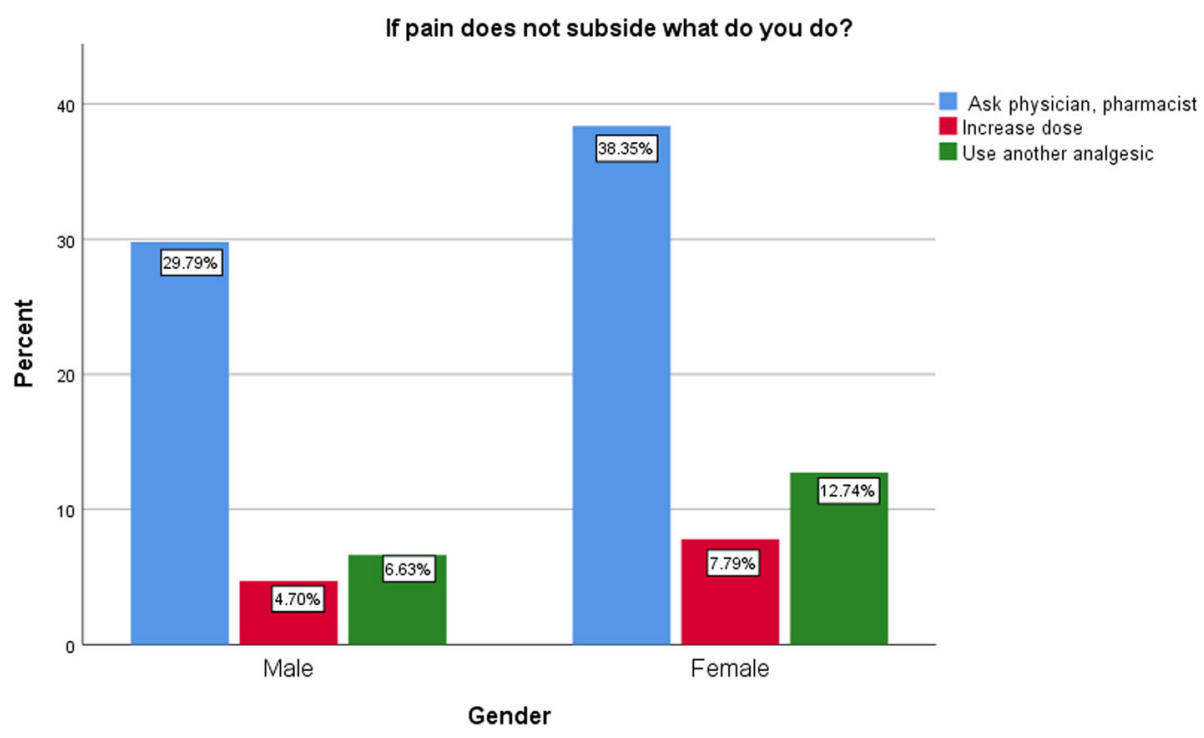

Fig. 2 The percentage of gender by if the pain did not subside, what do you do? 
Table 2 Knowledge and awareness of participant about analgesics $(n=1554)$

\begin{tabular}{|c|c|c|c|}
\hline Variables & & Number & Percent \\
\hline \multirow[t]{4}{*}{ Most commonly used analgesic } & Paracetamol or acetaminophen & 1202 & 77.3 \\
\hline & Ibuprofen & 275 & 17.7 \\
\hline & Aspirin & 28 & 1.8 \\
\hline & Other analgesic & 49 & 3.2 \\
\hline \multirow[t]{2}{*}{ When do you use analgesics? } & When needed & 1487 & 95.7 \\
\hline & Regularly & 67 & 4.3 \\
\hline \multirow[t]{3}{*}{ If the pain did not subside, what do you do? } & Ask physician, pharmacist & 1102 & 70.9 \\
\hline & Increase dose & 133 & 8.5 \\
\hline & Use another analgesic & 319 & 20.5 \\
\hline \multirow{3}{*}{$\begin{array}{l}\text { When you buy pain relief medication without a prescription, } \\
\text { what is your source of information about it? }\end{array}$} & Pharmacist, physician & 1059 & 68.1 \\
\hline & $\begin{array}{l}\text { I have heard about it through television, } \\
\text { radio, social media }\end{array}$ & 194 & 12.6 \\
\hline & Parents and friends & 301 & 19.3 \\
\hline \multirow[t]{3}{*}{ Do you think that increasing the analgesic dose has side effects? } & Yes & 1102 & 70.9 \\
\hline & No & 133 & 8.6 \\
\hline & I do not know & 319 & 20.5 \\
\hline
\end{tabular}

prevalent idea among the population in Saudi Arabia that paracetamol is completely safe. However, the National Prescribing Service MedicineWise (NPS MedicineWise) [22] indicates that this information is wrong.

In terms of students' knowledge, attitude, and practice regarding the use of analgesics, we found that most participants committed to a safe dose of analgesics, whereas a few took higher than the recommended daily dosage. It is important to note that the degree of knowledge in this study respect is high, as all of the study's participants are students at the university and have good knowledge and awareness in this aspect. This is consistent with the results of a similar study conducted by Karami et al. in Saudi

Table 3 Knowledge and awareness of participant about paracetamol or acetaminophen $(n=1554)$

\begin{tabular}{llll}
\hline Variables & Number & Percent \\
\hline $\begin{array}{l}\text { How may paracetamol tables } \\
\text { do you use daily? }\end{array}$ & $\begin{array}{l}\text { Once to twice } \\
\text { for every 4-6h }\end{array}$ & 777 & 50 \\
& $\begin{array}{l}\text { More than } 8 \\
\text { tablets within } \\
24 \mathrm{~h}\end{array}$ & 36 & 2.3 \\
& I do not use it & 741 & 47.7 \\
$\begin{array}{l}\text { Do you think that paracetamol } \\
\text { can lead to liver failure? }\end{array}$ & Yes & 1119 & 72.0 \\
$\begin{array}{l}\text { Do you know what the side } \\
\text { effects of paracetamol are? }\end{array}$ & Yes & 435 & 28.0 \\
$\begin{array}{l}\text { Do you have an idea about the } \\
\text { contraindications of Panadol? }\end{array}$ & Yes & 734 & 47.2 \\
\hline
\end{tabular}

Arabia in 2018 [16]. We have observed from the results of our study that there is an adequate awareness about the maximum safe dose of analgesics among the university student population. This is compatible with the results of the study conducted by Fendrick et al. in 2008 [23].

The usual number of paracetamol tablets used daily by most of the respondents is one to two every 4 to $6 \mathrm{~h}$. This dose is safe according to the NHS recommendations. The same is true for the aspirin and ibuprofen daily doses taken by participants. This indicates the participants' adequate knowledge and awareness about analgesic doses.

Table 4 Knowledge and awareness of participant about aspirin $(n=1554)$

\begin{tabular}{|c|c|c|c|}
\hline Variables & & Number & Percent \\
\hline \multirow[t]{4}{*}{$\begin{array}{l}\text { How may aspirin tables } \\
\text { do you use daily? }\end{array}$} & $\begin{array}{l}\text { More than } 6 \text { tablets } \\
\text { per day }\end{array}$ & 49 & 3.2 \\
\hline & 6 tablets per day & 24 & 1.5 \\
\hline & $\begin{array}{l}\text { Less than } 6 \text { tablets } \\
\text { per day }\end{array}$ & 95 & 6.1 \\
\hline & I do not use it & 1386 & 89.2 \\
\hline \multirow{2}{*}{$\begin{array}{l}\text { Do you have an idea about } \\
\text { aspirin side effects? }\end{array}$} & Yes & 673 & 43.3 \\
\hline & No & 881 & 56.7 \\
\hline \multirow{3}{*}{$\begin{array}{l}\text { Do you think aspirin can } \\
\text { lead to bleeding? }\end{array}$} & Yes & 888 & 57.1 \\
\hline & No & 131 & 8.4 \\
\hline & I do not know & 535 & 34.4 \\
\hline \multirow{2}{*}{$\begin{array}{l}\text { Do you know the conditions } \\
\text { in which aspirin should not } \\
\text { be used? }\end{array}$} & Yes & 951 & 61.2 \\
\hline & No & 603 & 38.8 \\
\hline
\end{tabular}


Table 5 Knowledge and awareness of participant about ibuprofen $(n=1554)$

\begin{tabular}{llll}
\hline Variables & & Number & Percent \\
\hline $\begin{array}{l}\text { How may ibuprofen tables } \\
\text { do you use daily? }\end{array}$ & $\begin{array}{l}\text { Less than 4 } \\
\text { tablets per day }\end{array}$ & 310 & 19.9 \\
& $\begin{array}{l}\text { Once to twice } \\
\text { for every 4-6h }\end{array}$ & 105 & 6.8 \\
& $\begin{array}{l}\text { More than 4 } \\
\text { tablets per day }\end{array}$ & 20 & 1.3 \\
& I do not use it & 1119 & 72 \\
& Yes & 648 & 41.7 \\
$\begin{array}{llll}\text { Do you have an idea about } \\
\text { the side effects of ibuprofen? }\end{array}$ & No & 906 & 58.3 \\
$\begin{array}{l}\text { Do you think that ibuprofen is } \\
\text { associated with stomach ulcers? }\end{array}$ & Yes & 990 & 63.7 \\
$\begin{array}{l}\text { Do you know what the } \\
\text { contraindications of ibuprofen are? }\end{array}$ & Yes & 564 & 36.3 \\
& No & 838 & 46.1 \\
\hline
\end{tabular}

Unfortunately, we found that there was poor awareness of the side effects of analgesics. This gives us an indication of the poor education about medicines in society, as we were expecting that the sample group should be the class with the highest level of knowledge in the community and could pass it on to the rest of the population.

\section{Limitations}

The present study dealt only with students' knowledge and awareness about the use of analgesics. Future studies should address the same problem with a more diverse sample of multiple populations and more analgesic medication. In addition, we conducted this study in one educational facility. Future research should focus on all university education facilities in Saudi Arabia.

\section{Conclusion}

The most commonly used analgesic among Taif University students is paracetamol, and the majority of Taif University students use over-the-counter analgesic medications without being aware of their contraindications and side effects. Our recommendation is to conduct a health education campaign about the use of analgesics.

\section{Acknowledgements}

We would like to thank the Saudi Association for Scientific Research (SASR) for providing their intellectual, technical, and logistical support throughout the project. We would also like to thank A. Sarriyah, A. Alshehri, N. Alamri, A Alharthi, F. Alharthi, N. Althumali, M. Alharthi, R. Al-Holaifi, R. Alharthi, and H. Alshehri for collecting the data.

\section{Authors' contributions}

AS is the main author; she supervised and reviewed all the steps. AQ analyzed the data and wrote or rewrote the manuscript. MT participated in writing the proposal and the results in the manuscript. SB participated in writing the proposal and the conclusion in the manuscript. ASh participated in writing the proposal and the introduction/background in the manuscript. AT participated in writing the proposal and the methods in the manuscript. All authors have read and approved the final manuscript.
Funding

Not applicable

\section{Availability of data and materials \\ Not applicable}

Ethics approval and consent to participate

The ethics approval was obtained from the Human Research Ethics

Committee, Taif University, Taif, Saudi Arabia. The consent of the participants was written.

\section{Consent for publication}

Not applicable

\section{Competing interests}

The authors declare that they have no competing interests.

\section{Author details}

${ }^{1}$ Anaesthesia Department, College of Medical, Taif University, Taif City, Saudi Arabia. ${ }^{2}$ General Department of Research and Studies in Ministry of Health, Riyadh, Saudi Arabia. ${ }^{3}$ Medicine and Surgery, Medical College, Taif University, Taif City, Saudi Arabia.

Received: 2 August 2019 Accepted: 16 January 2020

Published online: 19 February 2020

\section{References}

1. Naveed S, Ghayas S, Jawed A, Kanwal F, Mohiuddin B, Sabeen E, Sabuhi B (2014) Unnecessary use of pain killer in different age groups. DHR Int J Med Sci 5(2):2014 (DHR-IJMS) ISSN: 2278-831X

2. Brune K, Patrignani $P$ (2015) New insights into the use of currently available non-steroidal anti-infammatory drugs. J Pain Res 8:105-118

3. Srebro Z, Somogyi E, Wiliński B, Góralska M, Wiliński J, Sura P (2006) Aspirin augments the concentration of endogenous hydrogen sulfide in mouse brain and liver. Folia Med Cracov 47:87-91

4. Wiliński B, Wiliński J, Somogyi E, Góralska M, Piotrowska J (2011) Paracetamol (acetaminophen) decreases hydrogen sulfide tissue concentration in brain but increases it in the heart, liver and kidney in mice. Folia Biol (Krakow) 59:41-44

5. Gupta A, Jakobsson J (2014) Acetaminophen, nonsteroidal antiinflammatory drugs, and cyclooxygenase-2 selective inhibitors: an update. Plast Reconstr Surg 134(4 Suppl 2):24S-31S

6. Kyle ME, Wang JC, Shin JJ (2015) Impact of nonaspirin nonsteroidal antiinflammatory agents and acetaminophen on sensorineural hearing loss: a systematic review. Otolaryngol Head Neck Surg 152:393-409

7. Ungprasert P, Cheungpasitporn W, Crowson CS, Matteson EL (2015) Individual non-steroidal anti-inflammatory drugs and risk of acute kidney injury: a systematic review and meta-analysis of observational studies. Eur J Intern Med 26:285-291

8. Anwar A, Anwar Jl, Delafontaine P (2015) Elevation of cardiovascular risk by non-steroidal anti-inflammatory drugs. Trends Cardiovasc Med. https://doi. org/10.1016/j.tcm.2015.03.006

9. Woroń J, Porębski G, Kostka-Trąbka E, Goszcz A (2007) Irrational use of drugs as a source of drug-induced diseases. Med Wiek Rozw 11:87-91 (in Polish)

10. Matoulkova P, Dosedel M, Ryzkova B, Kubena A (2013) Acta Pol Pharm Drug Res 70:333

11. Rolita L, Freedman M (2008) Over-the-counter medication use in older adults. J Gerontol Nurs 34(4):8-17.

12. Shah SNH, llyas M, Azhar S, Murtaza G (2013) Latin Am J Pharm 32:191-6

13. Ullah H, Khan SA, Bakht SM, Tehseen Y, Karim S et al (2012) Latin Am J Pharm 31:1367

14. Stosic R, Dunagan F, Palmer H, Fowler T, Adams I (2011) Responsible selfmedication: perceived risks and benefits of over-the-counter analgesic use. Int J Pharm Pract 19:236-245

15. Puszczewicz M (2007) Nonsteroidal anti-inflammatory drugs. Przew Lek 3: 32-38 (in Polish) http://www.indeks.mp.pl (in Polish)

16. Karami NA, Altebainawi AF, Alfarki SA et al (2018) Knowledge and attitude of analgesics use among Saudi population: a cross-sectional study. Int J Med Sci Public Health 7(2) https://www.scopemed.org/?mno=1003629

17. Chen J, Murtaza G, Nadeem N, Shao X, Siddiqi BG, Shafique Z, Ahmad S, Amjad ST, Haroon S, Tanoli M, \& Zhou MY (2014). A questionnaire 
based survey study for the evaluation of knowledge of Pakistani University teachers regarding their awareness about ibuprofen as an over the counter analgesic. (2014). Polish Pharmaceutical Society. 337342.

18. National Health Service. (https://www.nhs.uk/medicines)

19. Dale O, Borchgrevink PC, Fredheim OM, Mahic M, Romundstad P, Skurtveit $S$ et al (2015) Prevalence of use of non-prescription analgesics in the Norwegian HUNT3 population: impact of gender, age, exercise and prescription of opioids. BMC Public Health 15:461

20. Palos GR, Mendoza TR, Cantor SB, Aday LA, Cleeland CS (2004) Perceptions of analgesic use and side effects: what the public values in pain management. J Pain Symptom Manag 28:460-473

21. Sarahroodi S, Maleki-Jamshid A, Sawalha AF, Mikaili P, Safaeian L (2012) Pattern of self-medication with analgesics among Iranian university students in Central Iran. J Family Community Med 19:125-129

22. National Prescribing Service MedicineWise (NPS MedicineWise). (https:// www.nps.org.au/news/safe-and-appropriate-use-of-paracetamol-closing-theconsumer-knowledge-gap)

23. Fendrick AM, Pan DE, Johnson GE (2008) OTC analgesics and drug interactions: clinical implications. Osteopathic Med Prim Care 2:2. https://doi. org/10.1186/1750-4732-2-2

\section{Publisher's Note}

Springer Nature remains neutral with regard to jurisdictional claims in published maps and institutional affiliations.

\section{Submit your manuscript to a SpringerOpen ${ }^{\circ}$ journal and benefit from:}

- Convenient online submission

- Rigorous peer review

- Open access: articles freely available online

High visibility within the field

- Retaining the copyright to your article

Submit your next manuscript at $\boldsymbol{\nabla}$ springeropen.com 